Jurnal KIBASP (Kajian Bahasa, Sastra dan Pengajaran)

Volume 2, Nomor 1, Desember 2018

e-ISSN : 2597-5218

p-ISSN : 2597-520X

DOI: https://doi.org/10.31539/kibasp.v2i1.441

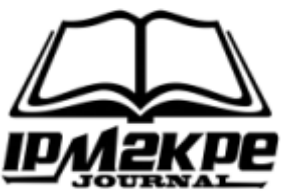

\title{
UPAYA MENINGKATKAN KEMAMPUAN MEMBACA MELALUI MEDIA PERMAINAN KARTU BERGAMBAR
}

\author{
Poniman \\ Sekolah Dasar Negeri 133 Seluma \\ poniman60@yahoo.com \\ Submit, 22-11-2018 Accepted, 23-12-2018 Publish, 23-12-2018
}

\begin{abstract}
ABSTRAK
Penelitian ini bertujuan untuk untuk mendeskripsikan bagaimana penggunaan Permainan kartu bergambar pada siswa kelas 1 SD Negeri 133 Seluma dan untuk meningkatkan kemampuan membaca Permulaan Bahasa Indonesia siswa kelas I SD. Penelitian ini merupakan Penelitian Tindakan Kelas (PTK) dilaksanakan dalam 2 siklus dengan 3 kali pertemuan tiap siklusnya dengan jumlah siswa sebanyak 10 siswa. Pada pra tindakan persentase ketuntasan siswa baru mencapai $50 \%$, setelah dilaksanakan tindakan pada siklus I persentase ketuntasan siswa meningkat menjadi $70 \%$, pada siklus II meningkat menjadi $80 \%$ sehingga peneliti tidak melanjutkan ke siklus III. Simpulan dalam penelitian ini, yakni dengan menerapkan pembelajaran dengan menggunakan media gambar dapat mengatasi kesulitan belajar membaca permulaan siswa kelas 1 SD Negeri 133 Seluma.
\end{abstract}

Kata Kunci: Permainan Kartu Bergambar, Membaca

\section{ABSTRACT}

This study aimed to describe how was the used of flash card for the first graders of SDN 133 Seluma and to improve early reading ability in Bahasa Indonesia. This is action research study with 2 cycles which has three meetings in each cycle and there were ten students as participants. Before treatment, the percentage of learning mastery was $50 \%$. The learning mastery improved $70 \%$ in cycle I after giving treatment then it also improved $80 \%$ in cycle II, therefore the researcher decided not to continue to cycle III. In conclusion, using flash card in learning process could solve students' difficulties in early reading stage of first graders of SDN 133 Seluma.

Keywords: Flash card, reading

\section{PENDAHULUAN}

Pada hakikatnya belajar bahasa adalah belajar komunikasi. Dengan pendekatan komunikatif ini siswa harus diberi kesempatan untuk melakukan komunikasi Baik secara lisan maupun tulisan (Depdiknas, 2000). Supaya siswa mampu berkomunikasi dengan menggunakan bahasa Indonesia yang baik dan benar, maka siswa perlu dilatih sebanyak-banyaknya atau diberi kesempatan seluas-luasnya untuk melakukan kegiatan 
berkomunikasi. Dengan mempertimbangkan karakteristik anak yang lebih memperhatikan terhadap sesuatu yang menarik perhatian mereka, membangkitkan minat dan motivasi belajar serta melatih imajinasi anak, maka penerapan media gambar dalam pembelajaran bahasa Indonesia khususnya untuk meningkatkan kemampuan bercerita anak dapat dilakukan secara optimal.

Salah satu fokus pembelajaran Bahasa di Sekolah Dasar yang memegang peranan penting ialah pembelajaran membaca, tanpa memiliki kemampuan membaca yang memadai sejak dini, anak akan mengalami kesulitan belajar dikemudian hari (Tarigan, 2006). Kemampuan membaca menjadi dasar utama tidak saja pembelajaran bahasa sendiri, tetapi juga bagi pembelajaran mata pelajaran lain (Wallinomo, 1991). Dengan membaca siswa akan memperoleh pengetahuan yang sangat bermanfaat bagi pertumbuhan dan perkembangan daya nalar, sosial dan emosional.

Peranan guru kelas I memegang peranan penting dalam bidang pengajaran Bahasa Indonesia khususnya membaca. Tanpa memiliki kemampuan membaca yang memadai sejak dini maka anak akan mengalami kesulitan belajar di kemudian hari. Kemampuan membaca menjadi dasar yang utama tidak saja bagi pengajaran Bahasa Indonesia sendiri, akan tetapi juga bagi pengajaran mata pelajaran lain.

Saat ini masih banyak guru yang belum melakukan fungsinya sebagai guru yang profesional. Masih banyak yang melalaikan tugas sebagai guru. Guru hanya bertugas menyelesaikan target materi dalam kurikulum setiap akhir semester atau setiap tahun. Namun, tidak memperhatikan masih terdapat ketidakseimbangan antara target kurikulum dengan daya serap yang dicapai peserta didik. Guru kurang mengenal siswa secara menyeluruh sehingga tidak bisa membedakan antara siswa yang lemah dengan siswa yang pandai dalam menerima pelajaran. Pembagian tugas mengajar kelas harus betul-betul sesuai kemampuan guru, khususnya guru kelas I harus guru yang bisa mengenal siswa secara keseluruhan.

Pembelajaran Bahasa Indonesia yang diterapkan di sekolah belum memanfaatkan media pembelajaran sebagai penunjang kegiatan pembelajaran. Dengan demikian perlu pemanfaatan media pembelajaran agar siswa mudah menangkap dan mencapai tujuan pembelajaran. Salah satu media pembelajaran yang dapat digunakan adalah media gambar (Syaiful, 2002). Media gambar ini menarik bagi siswa karena dari media tersebut banyak tema yang dapat dipilih untuk dikembangkan dan semua siswa 
memperoleh kesempatan yang sama selain itu mereka mendapatkan pengalaman yang berharga dan secara tidak langsung dapat meningkatkan minat mereka terhadap pembelajaran membaca.

Penggunaan metode permainan akan lebih efektif apabila didukung dengan adanya media sebagai alat bantu pembelajaran. Penggunaan alat bantu sebagai media pembelajaran diharapkan mampu membantu proses belajar seperti yang dikemukanan oleh Djauzak (2005), bahwa pemakaian media dalam proses pembelajaran dapat membangkitkan keinginan dan minat, membangkitkan motivasi, memberikan rangsangan kegiatan belajar, bahkan membawa pengaruh psikologis siswa. Media dapat menarik minat belajar dan konsentrasi anak untuk memahami pelajaran.

\section{METODE PENELITIAN}

Penelitian ini menggunakan penelitian tindakan kelas (classroom action research) yang berkolaborasi dengan teman sejawat. Suharsimi Arikunto (2006) yang mneyebutkan tujuan utama penelitian tindakan kelas ini adalah untuk memecahkan masalah yang nyata yang ada di kelas, yang tidak saja bertujuan memecahkan masalah, tetapi sekaligus mencari jawaban mengapa hal itu dapat dipecahkan melalui tindakan yang dilakukan. Penelitian ini dikembangkan secara bersama-sama oleh peneliti dan kolaborator untuk menentukan kebijakan dan pembangunan. Pada siklus (satu) siklus, yang terdiri dari tahap perencanaan, Pelaksanaan (action) dan refleksi atau perenungan. Berlanjut tidaknya ke siklus II tergantung dari hasil refleksi siklus I.

\section{HASIL PENELITIAN}

\section{Siklus I}

Tindakan siklus I dilaksanakan selama 2 minggu mulai tanggal 7 September 2017 sampai 15 September 2017. Penelitian ini dilaksanakan dengan menggunakan metode penelitian tindakan kelas yang terdiri siklus-siklus, tiap siklus terdiri dari 3 tahapan.

Guru sebagai pengelola pembelajaran di kelas mempersiapkan program tahunan, program semester, perencanaan pembelajaran dengan media gambar, lembar observasi, dan lembar tugas. Berdasarkan hasil observasi terhadap proses pembelajaran dan prestasi belajar sebelum tindakan, dapat diperoleh informasi data awal. Hasil pencatatan 
menunjukkan bahwa dari dari siswa kelas I sebanyak 30 siswa terdapat 20 siswa atau 70 \% yang masih belum mampu membaca permulaan dan mencapai KKM. Setelah dilakukan pemeriksaan pada lembar pekerjaan siswa, ternyata sebagian besar siswa masih belum dapat membedakan bentuk-bentuk huruf dan pemahaman siswa banyak yang terbalik membedakan huruf satu dengan yang lainnya.

Berdasarkan pengamatan dan pencatatan terhadap proses pembelajaran dan hasil belajar tersebut diperoleh informasi sebagai data awal bahwa siswa kelas I SD Negeri 133 Seluma sebanyak 30 siswa yang mana sebagian besar siswa belum dapat memahami/ menguasai bentuk-bentuk huruf, sehingga mereka masih kesulitan membedakannya dan terbalik menggunakannya. Bertolak dari kenyataan ada melaksanakan pembelajaran bahasa Indonesia dengan menggunakan media gambar untuk mengatasi kesulitan belajar membaca permulaan siswa kelas 1 SD Negeri 133 Seluma.

Dengan berpedoman pada standar kompetensi mata pelajaran bahasa Indonesia, guru kelas melakukan langkah-langkah pembelajaran bahasa Indonesia dilakukan dengan menggunakan media gambar. Berikut ini merupakan langkah-langkah yang dilakukan dalam proses persiapan pembelajaran, yaitu sebagai berikut :

1. Memilih pokok bahasan atau indikator yang sesuai dengan membaca permulaan. Indikator yang tepat untuk siklus I adalah siswa mampu mengucapkan huruf vokal dan konsonan.

2. Menyusun rencana pembelajaran berdasarkan indikator yang telah dibuat. Rencana pembelajaran yang disusun oleh peneliti memuat 1 kali pertemuan, dalam waktu 2 jam pelajaran dilaksanakan dalam 1 minggu.

3. Menyiapkan media gambar yang akan digunakan dalam pembelajaran. Pada siklus I guru menggunakan media gambar yang di bawahnya ada nama dari gambar tersebut, namun hurufnya belum lengkap (masih ada yang kosong). Untuk itu siswa diminta melengkapi huruf apa yang tepat untuk mengisi bagian yang kosong tersebut. Pada siklus I ini, guru menggunakan gambar yang nama di bawahnya terdapat huruf yang kosong baik di depan, tengah, maupun di belakang, dan siswa diminta untuk melengkapinya.

Dalam tahap ini guru menerapkan pembelajaran dengan menggunakan media gambar sesuai dengan rencana pembelajaran yang telah disusun. Pembelajaran yang 
telah disusun pada siklus I dengan menggunakan media gambar ini dilaksanakan dalam 1 kali pertemuan. Pada pertemuan pada siklus I materi bahasa Indonesia yang diajarkan tentang membaca permulaan dengan indikator mengucap huruf vokal dan konsonan sampai mampu membaca suku kata. Kemudian diawali dengan berdoa bersama, kemudian diajukan absensi siswa. Pada penelitian siklus I ini, guru memilih pokok bahasan tentang rekreasi.

Alasan memilih pokok bahasan rekreasi karena media gambar yang akan digunakan guru sebagian besar adalah gambar binatang. Tujuannya agar siswa lebih tertarik dengan pelajaran dan aktif dalam mengikuti proses pembelajaran. Setelah kegiatan berdoa bersama dan absensi siswa selesai, kemudian guru mengawali pelajaran dengan appersepsi. Setelah appersepsi, guru mulai memasuki materi dengan menggunakan media gambar. Media gambar yang digunakan pada siklus I ini adalah gambar binatang yang dibawahnya terdapat nama dari binatang tersebut. Tulisan nama binatang tersebut hurufnya tidak lengkap, jadi siswa diberi tugas untuk melengkapinya. Kegiatan itu dilaksanakan secara berulang-ulang hingga indikatornya dapat tercapai, yaitu mampu mengucapkan huruf vokal dan konsonan. Contoh dari kegiatan tersebut adalah: misalnya guru menunjukkan gambar burung, dan di bawah gambar tersebut ada tulisan nama dari gambar tersebut. Tulisan tersebut adalah B....RUNG, kemudian siswa diminta menyebut huruf apa yang tepat untuk melengkapi kata tersebut.

Secara rinci jalannya kegiatan pada siklus I ini adalah sebagai berikut: Sebagai kegiatan awal, guru menunjukkan media yang berupa bentuk-bentuk huruf dari A sampai Z, kemudian siswa disuruh mengucapkan semua susunan huruf tersebut, dan juga hurufnya ditunjuk secara diacak. Kegiatan ini bertujuan supaya siswa ingat akan bentuk-bentuk huruf tersebut. Setelah kegiatan itu selesai, guru menunjukkan media gambar.

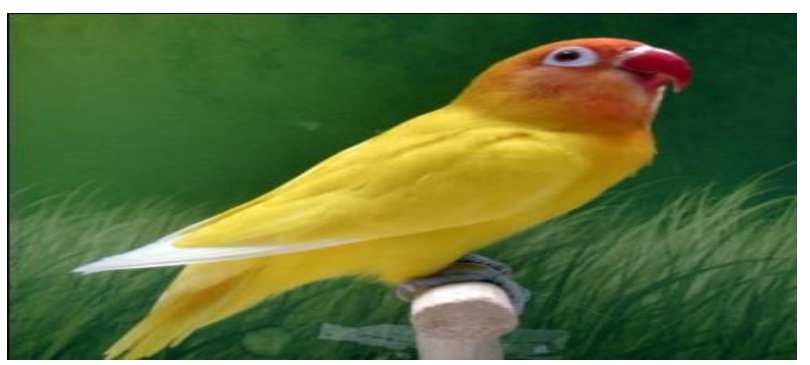

\begin{tabular}{|c|c|c|c|c|c|}
\hline B & & R & U & N & G \\
\hline
\end{tabular}

Huruf apa yang sesuai untuk mengisi kotak yang kosong? 
Kegiatan semacam ini diulang-ulang dengan gambar yang berbeda-beda sampai siswa mengetahui betul tentang materi yang diajarkan ( mampu mengucapkan huruf vokal dan konsonan). Untuk mengetahui keberhasilan materi, guru menunjuk salah satu siswa untuk menyebut nama dari gambar yang ditunjukkan oleh guru, dan menyebutkan huruf apa yang tepat untuk mengisi bagian yang kosong dari nama gambar tersebut, dan menulisnya di papan tulis.

Selama pelaksanaan penelitian tindakan kelas, guru melakukan pencatatan dengan menggunakan daftar observasi. Mendiagnosis keaktifan siswa, nilai yang dicapai siswa, tingkat ketertarikan siswa terhadap pelajaran, tingkat keantusiasan, keaktifan membaca permulaan, kemampuan membedakan huruf, dan kemampuan membaca permulaan siswa. Pada pelaksanaan siklus I ini, hasil observasi peneliti menunjukkan bahwa: keaktifan siswa sedang, nilai yang dicapai siswa sedang, tingkat ketertarikan siswa terhadap pelajaran sedang, tingkat keantusiasan sedang, keaktifan membaca permulaan sedang, kemampuan membedakan huruf rendah, dan kemampuan membaca permulaan siswa rendah.

Berdasarkan hasil observasi yang dilakukan selama proses pelaksanaan tindakan, baru 4 siswa yang sudah mulai menunjukkan adanya peningkatan. Para siswa tersebut sudah mulai mampu membedakan bentuk huruf dan sedikit-sedikit mampu melengkapi kata yang hurufnya kurang lengkap.

Berdasarkan hasil pengamatan selama proses pembelajaran berlangsung, siswa cukup aktif memperhatikan apa yang disampaikan guru dan mampu menjawab pertanyaan yang diajukan guru. Kemampuan siswa dalam membedakan bentuk huruf, pada siklus I sudah menunjukkan perubahan yang belum berarti, karena nilai rata-rata kelas hanya mencapai 70, namun siswa yang memperoleh nilai diatas KKM sebanyak 7 siswa atau $40 \%$ dari 10 siswa kelas I. Dengan demikian nilai rata-rata kelas yang mencapai 60 dan siswa yang memperoleh nilai di atas KKM sebanyak 40\% menunjukkan bahwa pembelajaran yang menggunakan media gambar pada siklus I yang dilakukan belum berhasil, jadi perlu dilakukan penelitian lagi pada siklus 2 .

\section{Siklus II}

Berdasarkan hasil refleksi dan evaluasi pelaksanaan tindakan pada siklus I diketahui bahwa belum menunjukkan adanya peningkatan prestasi belajar yang 
memuaskan. Karena dari tiga indikator yang ditetapkan baru indikator nomor 1 dan 2 yang berhasil (mampu mengucapkan huruf vokal dan konsonan). Sedangkan indikator nomor 3, belum menunjukkan peningkatan prestasi belajar yang diinginkan. Oleh karena itu, peneliti dengan arahan dari para rekan guru dan kepala sekolah serta berbagai pertimbangan maka peneliti kembali mengulang pembelajaran materi bahasa Indonesia (membaca permulaan) dengan indikator mampu membaca suku kata dan kata dengan lafal yang tepat. Guru menunjukkan media gambar, setelah itu siswa menyebutkan hurufnya. Setelah siswa selesai menyebutkan huruf-huruf tersebut, guru menyuruh siswa untuk membaca suku katanya.
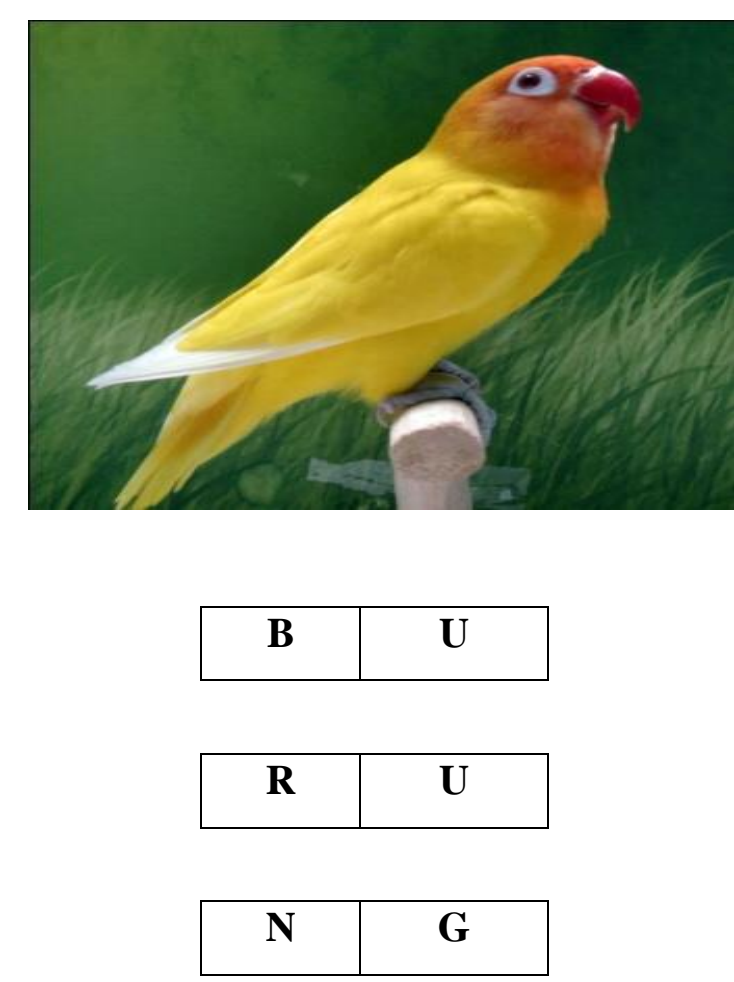

\section{Bacalah suku katanya dengan tepat dan nyaring !}

Langkah-langkah penyusunan rencana pembelajaran seperti siklus I. indikator yang tepat untuk siklus 2 adalah siswa mampu mengucapkan suku kata/kata dengan lafal yang tepat. Adapun indikator yang dibuat sebagai dasar penyusunan rencana pembelajaran pada siklus 2 adalah sebagai berikut : (1) memilih/menentukan kompetensi dasar, hasil belajar dan indikator yang hendak dicapai, (2) mempersiapkan alat-alat/media yang akan digunakan, (3) menyusun rencana pelaksanaan pembelajaran (RPP) berdasarkan kesepakatan yang telah disepakati bersama. 
Mengingat hasil analisis siklus I, sebagian besar siswa masih mengalami kesulitan membaca suku kata/ kata dengan lafal yang tepat, maka rencana penelitian pada siklus 2 ini adalah peneliti menggunakan media gambar dan kartu suku kata. Langkah-langkah penyusunan rencana pembelajaran seperti siklus I. Indikator yang tepat untuk siklus 2 adalah siswa mampu mengucapkan suku kata/kata dengan lafal yang tepat. Adapun indikator yang dibuat sebagai dasar penyusunan rencana pembelajaran pada siklus 2 adalah sebagai berikut; (1) memilih/menentukan kompetensi dasar, hasil belajar dan indikator yang hendak dicapai, (2) mempersiapkan alatalat/media yang akan digunakan, (3) menyusun rencana pelaksanaan pembelajaran (RPP) berdasarkan kesepakatan yang telah disepakati bersama.

Mengingat hasil analisis siklus I, sebagian besar siswa masih mengalami kesulitan membaca suku kata/ kata dengan lafal yang tepat, maka rencana penelitian pada siklus 2 ini adalah peneliti menggunakan media gambar dan kartu suku kata. Pembelajaran bahasa Indonesia dengan penggunaan media gambar sesuai dengan rencana pembelajaran 1 kali pertemuan. Guru mengawali pembelajaran dengan berdoa bersama, mengabsen siswa, kemudian untuk memusatkan konsentrasi, siswa diajak tanya jawab tentang pelajaran yang lalu. Pada penelitian siklus 2 ini, guru memilih pokok bahasan tentang rekreasi. Setelah kegiatan berdoa bersama dan absensi siswa selesai, kemudian guru mengawali pelajaran dengan appersepsi.

Setelah appersepsi, guru mulai memasuki materi dengan menggunakan media gambar. Media gambar yang digunakan pada siklus 2 ini adalah gambar binatang. Kemudian guru bertanya tentang nama dari gambar hewan tersebut. Setelah itu siswa ditugaskan untuk mengucapkan kata tersebut dan juga mengucapkan suku kata tersebut. Setelah kegiatan itu, secara bergiliran siswa disuruh menulis di papan tulis tentang nama dari gambar binatang tersebut. Selanjutnya siswa menyebutkan huruf apa saja yang terangkai menjadi kata/sebuah nama binatang tersebut. Kegiatan itu dilaksanakan secara berulang-ulang hingga indikatornya dapat tercapai, yaitu mampu mengucapkan suku kata/ kata dengan lafal yang tepat.

Peneliti, kepala sekolah, dan rekan guru secara kolaboratif melaksanakan observasi terhadap pelaksanaan pembelajaran dengan menggunakan media gambar. Observasi ini ditujukan pada kegiatan siswa, yaitu mendiagnosis keaktifan siswa, nilai yang dicapai siswa, tingkat ketertarikan siswa terhadap pelajaran, tingkat keantusiasan, 
keaktifan membaca permulaan, kemampuan membedakan huruf, dan kemampuan membaca permulaan siswa. Keseluruhan data yang diperoleh dalam kegiatan ini termasuk pencatatan hasil test akan digunakan sebagai bahan atau masukan untuk menganalisis perkembangan prestasi belajar membaca permulaan siswa. Hasil observasi pada siklus 2 adalah sebagai berikut : keaktifan siswa tinggi, nilai yang dicapai siswa sedang, tingkat ketertarikan siswa terhadap pelajaran tinggi, tingkat keantusiasan tinggi, keaktifan membaca permulaan sedang, kemampuan membedakan huruf tinggi, dan kemampuan membaca permulaan sedang.

Refleksi dilaksanakan oleh peneliti sebagai guru kelas I, hasil analisis data pada pelaksanaan pembelajaran dengan menggunakan media gambar pada siklus 2, secara umum telah menunjukkan perubahan yang cukup tinggi. Guru dalam melaksanakan pembelajaran semakin mantap dan luwes dengan memahami kekurangan-kekurangan kecil diantaranya kurang control waktu dan belum memberikan tindak lanjut. Presentase hasil belajar dan partisipasi siswa dalam pembelajaran terlihat meningkat drastis. Para siswa lebih banyak memperhatikan dan menjawab pertanyaan guru, lebih bersemangat, dan kreatif. Kemampuan dalam mengeja huruf menjadi suatu kata lebih meningkat, yang tentunya berpengaruh terhadap kemampuan dalam membaca permulaan. Dengan partisipasi siswa dalam pembelajaran yang semakin meningkat, suasana kelas pun menjadi hidup dan lebih menyenangkan. Dari analisis hasil test pada siklus 2 ini diketahui bahwa nilai rata-rata siswa adalah 67,5 dan siswa yang memperoleh nilai di bawah batas KKM sebanyak 1 siswa atau $10 \%$.

Dari penelitian ini pembelajaran dikatakan berhasil apabila partisipasi siswa dalam pembelajaran meningkat. Selain itu hasil yang dicapai siswa melalui test akhir pembelajaran mencapai nilai rata-rata kelas 77 dan presentase siswa yang memperoleh nilai di atas KKM sebanyak 90\%. Atas dasar ketentuan tersebut dan melihat hasil yang diperoleh pada masing-masing siklus, maka pembelajaran membaca permulaan yang menggunakan media gambar yang dilaksanakan pada siklus 2 sudah berhasil sehingga tidak perlu dilanjutkan ke siklus berikutnya.

\section{PEMBAHASAN}

Pembelajaran bahasa Indonesia dengan materi membaca permulaan sudah bisa dikatakan berhasil. Hal tersebut terbukti nilai membaca permulaan siswa dari sebelum 
tindakan sampai pelaksanaan siklus 2 terus meningkat, dan nilai rata-rata kelas pun naik. Semula sebelum tindakan, nilai bahasa Indonesia dengan materi membaca permulaan rata-rata kelasnya hanya 50.

Setelah diadakan tindakan, yaitu mengajar dengan menggunakan media gambar, pada siklus 1 nilai rata-ratanya naik menjadi 70. Pada siklus 1 ini masih terdapat 6 siswa yang nilainya belum mencapai KKM, maka peneliti melanjutkan penelitian siklus 2 . Pada siklus 2 ini, nilai rata-rata kelas naik menjadi 67, 5. Maka, tidak dilanjutkan ke siklus 3 karena sudah mencapai $80 \%$ siswa yang berhasil. Pada siklus 3 ini, presentase siswa yang sudah berhasil pembelajaran membaca permulaannya adalah sebanyak $90 \%$ dengan nilai rata-rata $85 \%$.

Pada penelitian ini, masih terdapat 1 siswa yang nilainya belum mencapai KKM. Hal tersebut terjadi karena faktor dari siswa itu sendiri. Siswa tersebut memiliki sifat yang pemalas, kurang motivasi dari orang tua, di rumah tidak ada yang mau membimbing belajar, dan pada saat mengikuti pelajaran selalu bermain sendiri. Setiap kali dinasehati guru, siswa tersebut diam, namun tidak menghiraukan. Siswa tersebut tetap bermain tanpa merespon pelajaran, karena dengan alasan malas belajar. Mengajar dengan menggunakan media gambar ini mampu menumbuhkan siswa lebih mudah mengingat bentuk huruf, cara mengucapkan huruf, cara mengeja suku kata, dan cara membaca suatu kata, sehingga siswa menjadi lebih termotivasi dan tertarik dalam pelajaran membaca permulaan.

\section{SIMPULAN}

Berdasarkan hasil penelitian ini, penggunaan media gambar dalam pembelajaran dapat mengatasi kesulitan belajar membaca permulaan pada siswa kelas 1 SD Negeri 133 Seluma dibandingkan dengan pembelajaran yang sebelum menggunakan media gambar. Hal ini dapat diketahui dari rata-rata prestasi belajar siswa yang relatif lebih tinggi bila proses pembelajarannya menggunakan media gambar dibandingkan dengan nilai rata-rata siswa yang pembelajarannya sebelum menggunakan media gambar. Nilai rata-rata siswa yang pembelajarannya menggunakan media gambar adalah 67, 5, sedangkan nilai rata-rata siswa yang pembelajarannya sebelum menggunakan media gambar adalah 59. Dengan demikian berdasarkan penelitian tindakan kelas dengan menggunakan 2 siklus tersebut di atas, ternyata hipotesis yang dirumuskan telah 
terbukti kebenarannya, artinya bahwa ternyata dengan menerapkan pembelajaran dengan menggunakan media gambar dapat mengatasi kesulitan belajar membaca permulaan siswa kelas 1 SD Negeri 133 Seluma.

\section{DAFTAR PUSTAKA}

Ahmad Djauzak. (1995). Metodik Khusus Pengajaran Bahasa Indonesia di Sekolah Dasar. Jakarta: Depdikbud

Arikunto, Suharsimi. (2006). Evaluasi Pendidikan. Jakarta: Pustaka Setia

Depdiknas. (2000). Permainan Membaca dan Menulis di Taman Kanak-Kanak. Jakarta: Depdiknas.

Djago Tarigan. (2006). Pendidikan Bahasa dan Sastra Indonesia di Kelas Rendah. Jakarta: Universitas Terbuka.

Djamarah, Bahri Syaiful. (2002). Psikologi Belajar. Jakarta: Rineka Cipta.

Hasan Wallinomo. (1991). Pengajaran Membaca dan Menulis Kelas I, II di SD. Jakarta: Dekdikbud. 